\title{
EFFECT OF EMPLOYEE RETENTION ON ORGANIZATIONAL PERFORMANCE
}

\begin{abstract}
Unzilla Khan
ABSTRACT

Employee retention continues to pose one of the greatest challenges facing organizations and managers today with the loss of valuable talent incurring heavy costs to the organization in terms of institutional know-how as well as the time, money, and efforts needed to recruit and train replacements. The purpose of this research is thus to observe the impact of retention on the organizational performance. Career development, Supervisor support, Work environment and Rewards are the key variables employed in this research. The variables lead on reflecting how they influence towards employee retention that is how much impact they have on towards retaining the employees which ultimately will have an impact on the organization's performance. The findings of this study will help determine the key elements that lead to employee retention in business organizations is Pakistan.
\end{abstract}

\section{INTRODUCTION}

\section{Background of the Study}

In the past years as well as in our current era, we have examined a lot of reasons as to why the employees leave the organization. A large amount of data is available which reflects on the reasons for retention of employees. As we are entering into the advanced era retention has always been a key factor, which is rapidly growing and becoming more challenging for the organizations in order to facilitate and retain their employees. Employee retention continues to pose one of the greatest challenges facing organizations and managers today (Pregnolato, Bussin, \& Schlechter, 2017), with the loss of valuable talent incurring heavy costs to the organization in terms of institutional know-how as well as the time, money, and efforts needed to recruit and train replacements. With a large pool of candidates, it is both a risk and challenge for the head hunters to play their part wisely. They need to examine closely not only for those who they hire but also to those employees who are still an active part of the organization. 
In the current climate of intense competition for talent among businesses worldwide, high turnover is an ever greater threat. As more and more organizations begin to offer higher rewards systems that foster individual career development, others are having to seriously address their own retention strategies. For organizations to keep up with their competitors and guarantee the growth of their businesses, such strategies must effectively ensure employee satisfaction, enhance employee performance, and ultimately safeguard against high turnover (Nwokocha \& Iherirohanma, 2012; Ramlall, 2004). Organizations need to actively seek out ways to work on employee retention and reducing the turnover.The reasons that have emerged are multiple. A combination of job pressure, lack of job satisfaction, and low commitment to the organization is cited as leading to employees' resignation (Firth, Mellor, Moore, \& Loquet, 2007). Less recognition or rewards are also an important factor when it comes towards employee retention. With this advanced technological era, organizations must realize that the employee scope has increased; they have the access to switch easily and in a glance. Therefore it is very crucial for organizations to keep their employees motivation level high with intrinsic or extrinsic rewards. It is the job of the Human resource to manage their resources well and to bring new innovations that would be beneficial not only to the employees but also for the organizations. To open new opportunities for all the employees and engage them with more challenging work and task. A company that wants to strengthen its bond with its employees must invest in the development of their employees (Hall \& Moss, 1998; Hsu, Jiang, Klein \& Tang, 2003; Steel et al., 2002; Woodruffe, 1999). The Human resource department should also find ways to train their managers, supervisors on how to deal with their sub ordinates and employees. One of the most important factors that have impact on retention is the relationship between a worker and a supervisor. Supervisors are the "human face" of an organization. According to Eisenberger and associates (1990), a worker's view of the organization is strongly influenced by their relationship with their supervisor. By having support, workers are less likely to leave an organization and be more engaged by having good relationship and open communication with the supervisor (Greenhaus, 1987). As in today's organization, diverse workforce is being utilized which arises the importance of supervisor and employee relationship for retention. Borstorff \& Marker (2007) found that employees want trustful supervisors who know them, understand them and treat them fairly. Abusive supervisors create conflicts in worker's attitude for job, life and organization. According to Kaliprasad (2006), the employee retention capacity of an organization totally relies on the organization's capability to manage its human resources 
well; it is well noted that unhappy employees will lean toward leaving their organization (Schuler \& Jackson, 2006).

Many studies have shown that work environment is also a big factor when it comes towards employee resignations. The new generation is much more linked with advanced technology and they seek new ways and creativity at work places as well. Failure on the part of managers to understand and adjust appropriately to generational differences and the demands of new generations entering the workplace can result in misunderstandings, miscommunications, and mixed signals (Fyock, 1990), and can affect employee productivity, innovation, and corporate citizenship (Kupperschmidt, 2000), ultimately resulting in problems with employee retention and turnover. Research also suggests that differences between generations in the workforce can be a significant source of conflict in organizations (e.g. Adams, 2000; Bradford, 1993; Jurkiewicz, 2000; Karp et al., 1999; O’Bannon, 2001). A good working environment is the one that is employee focused, which focuses on developing and bringing innovations to make employee feel valued. In such a competitive era, were employees are looking forward for new opportunities and better career growth it is much more challenging situation for organizations to tackle and find ways to retain employees.

Without valuable employees, a business cannot generate revenue and prosper. Every individual have a purpose to perform and without single one, the picture becomes invisible to be successful in real manner. Retaining the employees is the most important target for the organization because sometimes the high salary or the designation is not important for the employee to stay in the organization. Through this research we will be able to find out how valuable employees would be retained by focusing on certain determinants i.e. career development opportunities, supervisor support, work environment, rewards. To attract employees and for bringing innovation in order to make an effort in terms of retaining employees in the company. The companies must work on generating new ideas and to cope up with the existing issue to be able to be the best organization which is employee focused rather than task or work.

\section{PROBLEM STATEMENT}


Through this study we will be able to identify how these factors career development, reward, work environment and supervisor support influence on the organization performance. This research will guide organizations to seek new ways to work on employee retention. Our research particularly focuses on Business organizations. With the advancement of technological era and new generation the organizations should realize that they need to work on bringing innovation and open new opportunities so that they will be able to retain these employees which would not only be beneficial to the employees but the organization as well.

\section{RESEARCH QUESTIONS}

\begin{tabular}{|c|c|c|}
\hline Variables & Items & Citation \\
\hline \multicolumn{3}{|c|}{ Career development opportunities } \\
\hline Q1. & $\begin{array}{l}\text { A company that wants to strengthen its } \\
\text { bond with its employees must invest in the } \\
\text { development of their employee. }\end{array}$ & $\begin{array}{l}\text { (Hall \& Moss, 1998; } \\
\text { Hsu, Jiang, Klein \& } \\
\text { Tang, 2003; Steel et al., } \\
\text { 2002; } \quad \text { Woodruffe, } \\
\text { 1999). }\end{array}$ \\
\hline Q2. & $\begin{array}{l}\text { It's a mutual benefit process because } \\
\text { career development provides the } \\
\text { important outcomes for both parties }\end{array}$ & $\begin{array}{l}\text { (Hall, 1996; Kyriakidou } \\
\text { and Ozbilgin, 2004). }\end{array}$ \\
\hline Q3. & $\begin{array}{l}\text { Organizations need talented employees } \\
\text { for maintaining the sustainable } \\
\text { competitive advantage and individuals } \\
\text { require career opportunities to develop } \\
\text { and grow their competencies }\end{array}$ & (Prince, 2005). \\
\hline \multicolumn{3}{|c|}{ Supervisor Support } \\
\hline Q1. & $\begin{array}{l}\text { According to Eisenberger and associates } \\
\text { (1990), a worker's view of the } \\
\text { organization is strongly influenced by } \\
\text { their relationship with their supervisor }\end{array}$ & $\begin{array}{l}\text { Eisenberger } \\
\text { associates (1990), }\end{array}$ \\
\hline Q2. & $\begin{array}{l}\text { By having support, workers are less likely } \\
\text { to leave an organization and be more } \\
\text { engaged by having good relationship and } \\
\text { open communication with the supervisor }\end{array}$ & (Greenhaus, 1987) \\
\hline Q3. & $\begin{array}{l}\text { If the relationship does not exceed then } \\
\text { employee will seek to any other } \\
\text { opportunity for new employment and vice } \\
\text { versa. The supervisor support is so }\end{array}$ & (Ontario, 2004). \\
\hline
\end{tabular}




\begin{tabular}{|c|c|c|}
\hline & $\begin{array}{l}\text { essential to retention that it can be said } \\
\text { that employees leave bosses, not jobs }\end{array}$ & \\
\hline \multicolumn{3}{|c|}{ Work Environment } \\
\hline Q1. & $\begin{array}{l}\text { Numerous studies have attempted to } \\
\text { explain work environment in various } \\
\text { areas such as for example employee } \\
\text { turnover (Martin 1979), job satisfaction } \\
\text { (Iaffaldano \& Muchinsky, 1985), } \\
\text { employee turnover, job involvement and } \\
\text { organizational commitment (Sjöberg \& } \\
\text { Sverke 2000). }\end{array}$ & $\begin{array}{l}\text { (Martin 1979), } \\
\text { (Iaffaldano } \quad \& \\
\text { Muchinsky, 1985), } \\
\text { (Sjöberg \& Sverke } \\
\text { 2000). }\end{array}$ \\
\hline Q2. & $\begin{array}{l}\text { The focus of organizations must be on } \\
\text { how to provide better jobs with great work } \\
\text { environment to retain employees }\end{array}$ & (Lennart Levi, 2002). \\
\hline Q3. & $\begin{array}{l}\text { It's very important to recognize the } \\
\text { emerging needs of individuals to keep } \\
\text { them committed and provide the work } \\
\text { environment as necessitate }\end{array}$ & (Ramlall, 2003) \\
\hline Q4. & $\begin{array}{l}\text { Milory (2004) reported that people enjoy } \\
\text { working, and strive to work in those } \\
\text { organizations that provide positive work } \\
\text { environment where they feel they are } \\
\text { making difference and where most people } \\
\text { in the organization are proficient and } \\
\text { pulling together to move the organization } \\
\text { forward. }\end{array}$ & Milory (2004) \\
\hline \multicolumn{3}{|c|}{ Rewards } \\
\hline Q1. & $\begin{array}{l}\text { The term 'reward' is discussed frequently } \\
\text { in the literature as something that the } \\
\text { organization gives to the employees in } \\
\text { response of their contributions and } \\
\text { performance and also something which is } \\
\text { desired by the employees. }\end{array}$ & (Agarwal, 1998). \\
\hline Q2. & $\begin{array}{l}\text { A reward can be extrinsic or intrinsic it } \\
\text { can be a cash reward such as bounces or it } \\
\text { can be recognition such as naming a } \\
\text { worker employee of the month, and at } \\
\text { other times a reward refers to a tangible } \\
\text { incentive, reward is the thing that an } \\
\text { organization gives to the employee in } \\
\text { response of their contribution or } \\
\text { performance so that the employees } \\
\text { become motivated for future positive } \\
\text { behavior. In a corporate environment } \\
\text { rewards can take several forms. It } \\
\text { includes, cash bonuses, recognition } \\
\text { awards, free merchandise and free trips. }\end{array}$ & (Silbert, 2005). \\
\hline
\end{tabular}




\begin{tabular}{|l|l|l|}
\hline Q3. & $\begin{array}{l}\text { It is very important that the rewards have } \\
\text { a lasting impression on the employee and } \\
\text { it will continue to substantiate the } \\
\text { employee's perception that they are } \\
\text { valued. }\end{array}$ & $\begin{array}{l}\text { Attractive remuneration packages are one } \\
\text { of the very important factors of retention } \\
\text { because it fulfills the financial and } \\
\text { material desires as well as provide the } \\
\text { means of being social by employee's } \\
\text { status and position of power in the } \\
\text { organization. Many researchers } \\
\text { demonstrate that there is a great deal of } \\
\text { inter-individual difference in } \\
\text { understanding the significance of } \\
\text { financial rewards for employee retention }\end{array}$ \\
\hline
\end{tabular}

\section{RESEARCH OBJECTIVES}

The purpose of this research is to observe the impact of retention on the organization performance. Career development, Supervisor support, Work environment and Rewards are the factors and key variables of the research which would lead on reflecting how they influence towards employee retention that is how much impact they have on towards retaining the employees which ultimately will have an impact on the organizations performance. The main focus of this research will be on the Business organizations.

\section{SIGNIFICANCE OF STUDY}

This research will provide guidance to the business organizations. They HR people should be able to work on generating new opportunities and bring new challenges for their employees. The new generation is much more advance, and they are willing to accept challenges and seek new opportunities. The organizations need to train their managers on how to treat their subordinates and other employees. By creating an environment which will give an open space and open culture to employees to share their opinions and feel valued. These organizations should be people oriented rather than just profit oriented. The HR people should work on finding new techniques and encouraging more reward system in the organizations. An organization should also focus on creating a work environment where they can easily work and the HR should recognize the emerging needs of every individual's to keep them committed and provide them with every necessity. Employee retention is most critical issue facing corporate 
leaders as a result of the shortage of skilled labor, economic growth and employee turnover. Retention is defined as "the ability to hold onto those employees you want to keep, for longer than your competitors" (Johnson, 2000). With the implementation of these in the organizations they will be able to retain the employees and ultimately be benefited by it for a longer period with more commitment and success these organizations will flourish and create a culture or diversity, challenges, and valuing every individual. This would create an impact on reducing turnover and help in reducing employee retention.

\section{LIMITATIONS OF THE STUDY}

The research sample will only be implemented in Pakistan and will target the business organizations in Karachi. This research will be applicable on both FTE and PTE. Keeping the current situation this research will also be applicable on WFH employees as well and the other positions will be junior, senior, middle and upper level of management will be its target for the collection of data. (This will also include the Management trainee and Interns in the organization). The questionnaire will be filled by each to get the end results and outcomes which will reflect that how employee retention influences on the overall organization performance. This research will not be applicable on schools.

\section{SCOPE OF THE STUDY}

This study will be applicable in Pakistan, particularly Karachi and the results and recommendations will be beneficial for the business organizations in Karachi, Pakistan. This will help the organizations to create a more employee oriented and valued culture to help them in retaining the employees.

\section{LITERATURE REVIEW}

\section{Employee Retention}

Employee retention is most critical issue facing corporate leaders as a result of the shortage of skilled labour, economic growth and employee turnover. Retention is defined as "the ability to hold onto those employees you want to keep, for longer than your competitors" (Johnson, 2000). Managing turnover is a challenging part for the organization. A number of studies show that not just nowadays, but previously as well it was a difficult task for organizations to be able to retain their employees and keep them motivated. Today the demands of workers have been 
increased very much as ever before. It is in terms of every aspect, not only salaries and perks but also work experience and cultural context in which it occurs. Providing a prolific, flexible and dynamic work environment can be a critical asset in attracting and retaining valuable employees. In order to develop an effective retention plan for today's employment market, it is vital to realize the varying needs and expectation. If the retention strategies are not properly embedded in the business processes, the all effort since recruitment will ultimately proves futile (Earle, 2003). In the current climate of intense competition for talent among businesses worldwide, high turnover is an ever greater threat. As more and more organizations begin to offer higher rewards systems that foster individual career development, others are having to seriously address their own retention strategies. For organizations to keep up with their competitors and guarantee the growth of their businesses, such strategies must effectively ensure employee satisfaction, enhance employee performance, and ultimately safeguard against high turnover (Nwokocha \& Iherirohanma, 2012; Ramlall, 2004)

\section{Career Development Opportunities}

Career development is a system which is organized, formalized and it's a planned effort of achieving a balance between the individual career needs and the organization's workforce requirements (Leiboiwitz et al, 1986). A company that wants to strengthen its bond with its employees must invest in the development of their employees (Hall \& Moss, 1998; Hsu, Jiang, Klein \& Tang, 2003; Steel et al., 2002; Woodruffe, 1999). Career development is important for both the organization and individual (Hall, 2002). It's a mutual benefit process because career development provides the important outcomes for both parties (Hall, 1996; Kyriakidou and Ozbilgin, 2004). Organizations need talented employees for maintaining the sustainable competitive advantage and individuals require career opportunities to develop and grow their competencies (Prince, 2005).

\section{Supervisor Support}

One of the most important factors that have impact on retention is the relationship between a worker and a supervisor. Supervisors are the "human face" of an organization. According to Eisenberger and associates (1990), a worker's view of the organization is strongly influenced by their relationship with their supervisor. By having support, workers are less likely to leave an organization and be more engaged by having good relationship and open communication with the supervisor (Greenhaus, 1987). As in today's organization, diverse workforce is being 
utilized which arises the importance of supervisor and employee relationship for retention. Borstorff \& Marker (2007) found that employees want trustful supervisors who know them, understand them and treat them fairly. Abusive supervisors create conflicts in worker's attitude for job, life and organization. Employees who feel esteemed will actively take part in organization's goals, exhibit prolific workplace behaviors such as increased in job involvement, reduced absenteeism and have less turnover rates. The means by which support from a supervisor can be revealed is by formal and informal recognition. In organization workforce responds to praise, encouragement and support, no matter the environment is personal or professional (Silbert, 2005). According to Freyermuth (2007), Organization must groom supervisors to well build the place where employees want to stay. Providing each level of performance and opportunities can enhance their capabilities to work (Otis and Pelletier, 2005).

\section{Work Environment}

Magnusson (1981) and Caplan (1987) have suggested that one of the most important tasks in psychology may be to examine the individual's perceptions of the outer world in interaction with their expectations about environments. We have known for some time that variables in the work environment impact employee behavior (Blumberg and Pringle, 1982; Kyriakidou and Ozbilgin, 2004; Niles and Harris-Bowlsbey, 2002; Olson and Borman, 1989; Peters et al., 1985). Numerous studies have attempted to explain work environment in various areas such as for example employee turnover (Martin 1979), job satisfaction (Iaffaldano \& Muchinsky, 1985). People placed in work environments that "fit" are more likely to intrinsically enjoy their work. The reverse is true for those placed in work environments that do not "fit". For these employees, normal daily work occurrences may be unpleasant and interpreted more negatively, thus resulting in negative outcomes such as boredom, poor work performance, and lack of satisfaction. Sub-par employee performance is often the result of psychological problems that are characteristic of a mismatch between an individual and his/her environment (Lubinsky, 2000). With the increasingly transitory nature of work, the reduction in lifelong employment and the increase in part-time and contract work (Sonnenberg, 1997), younger generation employees are more likely to be aware of the need for constant skill development and updating (Hesketh and Bochner, 1993). Rather than passively relying on employers to take responsibility for employee career development, younger generation employees are more likely to take a more active role in their career planning and execution. As a result, it is likely that if the 
younger generations' preferences are not realized in the work environment, the impatience and increased mobility of younger generation employees will manifest itself in higher levels of dissatisfaction. It's very important to recognize the emerging needs of individuals to keep them committed and provide the work environment as necessitate (Ramlall, 2003). According to Miller, Erickson \& Yust (2001), employees get benefited by work environment that provide sense of belonging. Firms with generous personalization policies may have better chance to satisfy and retain employees by providing appropriate level of privacy and sound control on workspace which enhances the motivation levels to commit with the organization for the long term (Wells \& Thelen, 2002).

\section{Rewards}

The term 'reward' is discussed frequently in the literature as something that the organization gives to the employees in response of their contributions and performance and also something which is desired by the employees (Agarwal, 1998). Rewards are very important for job satisfaction because it fulfills the basic needs as well as helps to attain the higher level of goals. Earnings is the way by which worker get to know that how much they are gaining by dedicating their time, effort and skills in a job (Bokemeier \& Lacy, 1986). Attractive remuneration packages are one of the very important factors of retention because it fulfills the financial and material desires as well as provide the means of being social by employee's status and position of power in the organization. Many researchers demonstrate that there is a great deal of interindividual difference in understanding the significance of financial rewards for employee retention (Pfeffer, 1998; Woodruffe, 1999). An organization's reward system can affect the performance of the employee and their desire to remain employed (e.g., Bamberger \& Meshoulam, 2000, MacDuffie, 1995).

\section{Impact of Career Growth Opportunities on Employee Retention}

If more career opportunities are provided then the employee retention will be enhanced to a great deal. This research reveals that employees feel to be retained in the organization where the jobs and careers are very well defined, get frequent opportunities to grow, get range of professional experiences, broad functional and geographic exposure within the organization and more targeted opportunities. Such desirable offers lead them to stay and continue to grow with their company 


\section{Impact of Supervisor Support on Employee Retention}

If employees are endowed with more supervision support then the employee retention will be increased to a great deal. Support from a supervisor is a major contributor to a person's performance and effectiveness. Considering the amount of valuable contributions and care for a person's well-being, all related to development, satisfaction, performance or effectiveness from the supervisor has an immense significance (Gentry et al. 2006).

\section{Impact of Work Environment on Employee Retention}

If employees are working in a very good environment then it will add considerable positive impact on employee retention. So, the research result reveals that the affect of work environment on employees is very much. It leads to feel employees happy and keep active to perform various job tasks. It is important to note that organizations exist in environments, in which they have been operated. Work environment influences especially when one considers employee retention

\section{Impact of Rewards on Employee Retention}

It acts as a reminder for employee about the special achievement and relish in those feelings a little longer which perhaps serve as encouragement to repeat the effort in future. The more frequently the employee sees thinks about, or uses the reward, the more the employee is expected to realize that he/she is valued by the organization; thereby it increased the level of Employee Retention. 


\section{THEORETICAL FRAMEWORK}

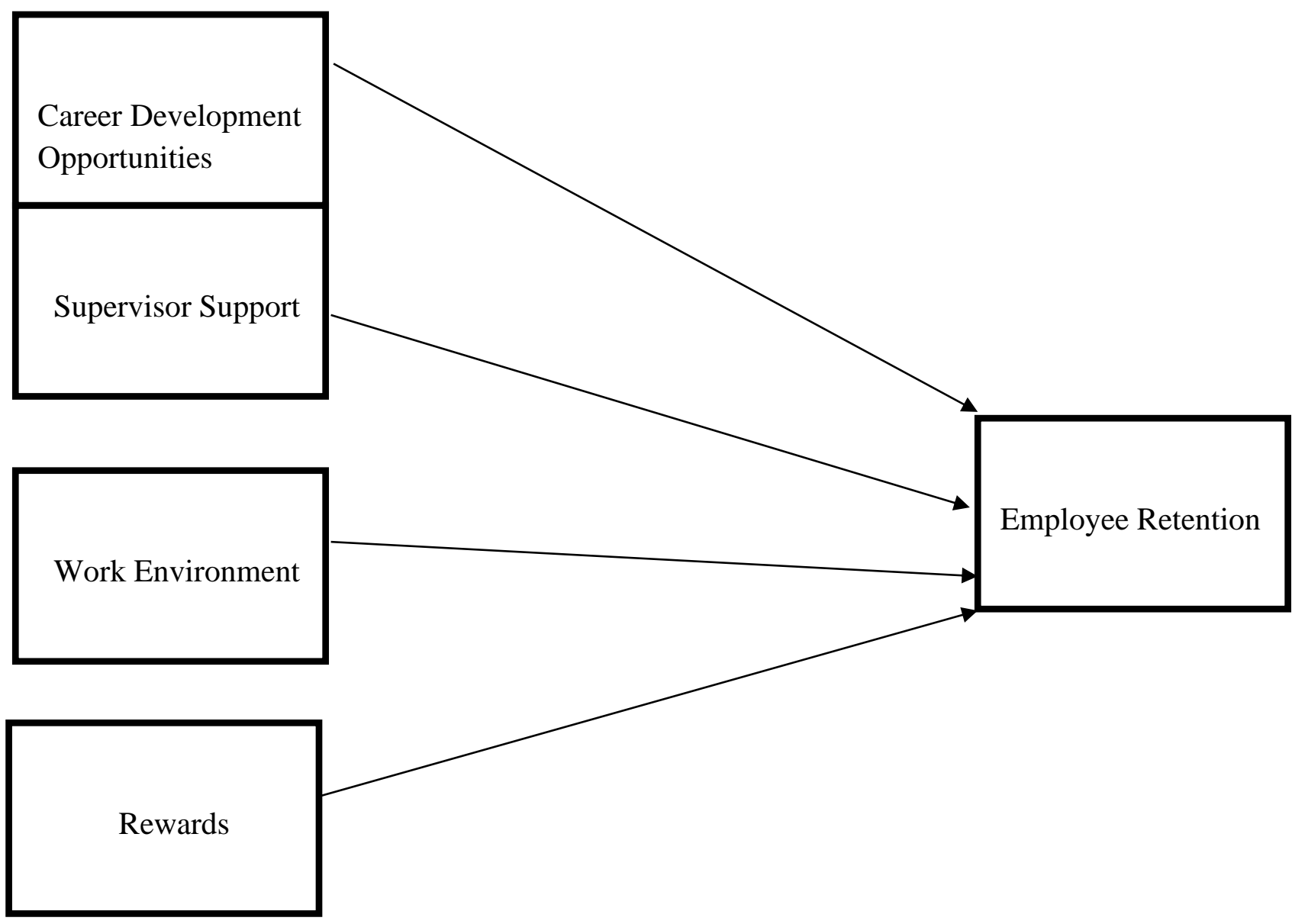

RESEARCH METHODOLOGY

\section{Research Design}

Our research type is quantitative research. The objective of the research used will be explanatory as we are doing theory testing. The scope of the research is applied as it will be applicable only in the business organizations in Pakistan. The method of research will be mono research as we are doing quantitative research only. The technique of the research will be secondary as we have taken some data from the business organization is Pakistan. The approach will be deductive it will be from general to specific as data will be collected only from Pakistan. The time horizon is cross sectional as will gather data from multiple business organizations in Pakistan. The data collection is secondary. The type of researcher investigation is correlation as there is no interference and the study setting is based on natural environment. 


\section{Population \& Sample}

The sampling technique will be probability sampling. Statistical technique used is inferential statistics as we conducted research on specific population that is the Business organizations in Pakistan. The sampling size considered is 384 . The population size is as this research is applicable only on all the business organizations located in Pakistan. It will cover all the cities in Pakistan. Probability sampling which is used is probability sampling.

\section{Instrumentation}

\section{Variables}

The variables present in the theoretical framework are used. According to this employee retention is dependent variable, which has a relationship with career development opportunities, work environment, reward and supervisor support. These variables are independent. If these independent variables will be focused by the organizations they will be able to retain and reduce the employee retention which will ultimately create a positive impact towards the organizations performance.

\section{Data Analysis Plan}

A five-point Likert scale was used to measure the questionnaire items, ranging from "Strongly agree" (1) to "Strongly Disagree" (5). The data analysis tool used was SPSS software through which we have deduced the results and claimed our hypothesis whether they accept or not. Thus, we concluded that the following main part to answer over claims.

\section{RESULTS}

\section{Descriptive statistics}

In terms of gender $(60 \%)$ were male and (40\%) were female and their age ranged from 18 to 60 years. In terms of marital status, (64\%) were single and (36\%) were married. In terms of status, (45\%) were students, (55\%) were employed. In terms of education, (2\%) had primary education, (6\%) had education up to secondary school certificate (SSC), (7\%) had a higher education certificate (HSC), (60\%) had bachelor's degrees, and the rest (23\%) had at least master's degree and in term of income $10 \%$ below $15000,60 \%$ were 15000 to $35000,20 \%$ were 35000 to 45000 and the rest $10 \%$ were 45 above. 


\section{Inferential statistics}

Below mentioned are the hypotheses formulated for this study to analyze the relationship between the independent variables and dependent variables, moreover the results of the hypothesis claim on employee retention:

H1: Increased number of career opportunities has a positive impact on employee retention.

H2: Increased number of rewards has a positive impact on employee retention.

H3: Higher level of supervisor support has a positive impact on employee retention.

H4: A good working environment has a positive impact on employee retention.

The data analyses prove that all the hypotheses' statements have been proved to be positive creating an impact on employee retention. It is observed that the employee retention has become a major part of research and is widely studied.

\section{CONCLUSION}

It is thus concluded that there is a relationship between independent variables and dependent variable which is identify with the help of sig value. The development of any organizations and firms is to achieve the higher productivity whereby the employees as functioning effectively and efficiently in an organizational system. The idea is that motivated and committed employees are essential conditions for accomplishing organizational goals. Human resource management (HRM) practices have to be addressed in this position, in order to examine the behaviors and performances of employees and to retain them for longer term. A major part of this study findings will help determine the key elements that lead to employee retention in business organizations is Pakistan. 


\section{REFERENCES}

Alhmoud, A., \& Rjoub, H. (2019). Total rewards and employee retention in a Middle Eastern context. SAGE Open, 9(2), 2158244019840118.

Cennamo, L., \& Gardner, D. (2008). Generational differences in work values, outcomes and person-organisation values fit. Journal of managerial psychology.

Crumpacker, M., \& Crumpacker, J. M. (2007). Succession planning and generational stereotypes: should HR consider age-based values and attitudes a relevant factor or a passing fad?. Public personnel management, 36(4), 349-369.

Glass, A. (2007). Understanding generational differences for competitive success. Industrial and commercial training.

Kupperschmidt, B. R. (2000). Multigeneration employees: strategies for effective management. The health care manager, 19(1), 65-76.

Prawitasari, G. (2018, October). The influence of generations on career choice (Social Cognitive Career Theory Perspective). In 1st ASEAN School Counselor Conference on Innovation and Creativity in Counseling. Ikatan Bimbingan dan Konseling Sekolah.

Shoaib, M., Noor, A., Tirmizi, S. R., \& Bashir, S. (2009). Determinants of employee retention in telecom sector of Pakistan. Proceedings of the 2nd CBRC, Lahore, Pakistan, 14(1), $1-18$.

Westerman, J. W., \& Yamamura, J. H. (2007). Generational preferences for work environment fit: Effects on employee outcomes. Career Development International. 